\title{
GIS Based Approach Estimation of Area under Wheat and Other Major Rabi Crops in District Ghotki and Corresponding Irrigation Water Requirement
}

\author{
Shoukat Ali Shah ${ }^{1 *}$ and Altaf Ali Siyal ${ }^{2}$ \\ ${ }^{1}$ Master of Engineering, Institute of Water Resources Engineering and Management, Mehran University of Engineering and Technology \\ Jamshoro, Pakistan \\ ${ }^{2}$ Professor, US-Pakistan Center for Advanced Studies in Water, Mehran University of Engineering and Technology Jamshoro, Pakistan \\ *Corresponding Author: Shoukat Ali Shah, Master of Engineering, Institute of Water Resources Engineering and Management, Mehran \\ University of Engineering and Technology Jamshoro, Pakistan.
}

Received: November 01, 2019; Published: November 18, 2019

DOI: $10.31080 /$ ASAG.2019.03.0725

\begin{abstract}
Accurate and reliable information about crop acreage, yield, and water requirements immediately after sowing is desirable for the local, regional and international agricultural markets to predict the grain prices well in advance. The present study was thus carried out to estimate the area under major Rabi crops and the corresponding irrigation water requirements for district Ghotki using GIS and Remote sensing tools. The field and historical data were gathered and analyzed statistically while satellite data was classified using ArcGIS 10.3 software. Based on satellite data, it was estimated that wheat was a major Rabi crop of Ghotki district during 2016-17, which was cultivated over an area of about 123427 ha, occupying about $19.39 \%$ of the total geographical area of the district. While, the sugarcane was second major Rabi crop, which was cultivated over an area of about 49116 ha in 2016-17, occupying about 7.72\% of the total geographical area of the district. A good linear and positive relationship between the wheat crop yield and the NDVI with a coefficient of determination of $\mathrm{R}^{2}=0.90$ was observed. A good relation between historical cultivated area and the total production of the wheat and sugarcane with $\mathrm{R}^{2}=0.85$ and $\mathrm{R}^{2}=0.97$ respectively was observed. The total irrigation water requirement for the district during Rabi season 2016-17 was estimated as 0.962MAF while the irrigation water distributed by the SIDA to the Ghotki district for the Rabi period was $0.72 \mathrm{MAF}$ at the field. Thus, a shortfall of $0.242 \mathrm{MAF}$ (or about 25.1\%) might have been supplemented from groundwater. Based on the present study it is recommended that Remote sensing and GIS tools should be used for timely, accurate and reliable cropped area estimation and yield forecast of agricultural products as well as irrigation water requirements in other districts of Sindh.
\end{abstract}

Keywords: Wheat; NDVI; Crop Water Requirement; GIS; Remote Sensing.

\section{Introduction}

Agriculture is an essential driving force in the management of water use. Water serves different uses, such as agricultural use, domestic and industrial use and environmental uses to maintain aquatic and terrestrial ecosystems. Water is a primary focus of global resource management, and national and international efforts continue to research the potential effects of water scarcity and accelerating water contamination. The mainstay of Pakistan's economy is agriculture sector. Pakistan's major exports comprise on agricultural products like wheat, rice, cotton, and other main crops. The agriculture sector is the backbone of Pakistan's economy which ensures poverty alleviation and food security. It shares $20.9 \%$ of Gross domestic production (GDP) in 2014-15, which makes it second largest contributor to GDP after services sector. The agriculture sector engages $43.5 \%$ of country labor force and is a major source of earning for rural people [1]. The agriculture 
mainly relies on irrigation as country's major cultivated area falls in semi-arid to arid climatic zones.

Wheat is the most widely grown crop in the world. Wheat (Triticum Aestivum), "King of the cereals" is an important staple food crop of Pakistan and is grown under different climatic conditions [2]. It is used as staple food by about $35 \%$ of the world population, and its demand is growing faster than other major food crops. It contributes 13.1 percent to the value added in agriculture and 2.8 percent to GDP of Pakistan. It was grown in around 9,062 thousand hectares of the area having an annual production of 23,421 thousand tones during 2008-09 [3]. However, the wheat yield in Pakistan is still quite low when compared to the world average. The share of this single item in total household consumption in Pakistan is about 9\%. Among rural households' wheat is the largest single consumption item, while among urban households' it is the second largest consumption item the following housing. Wheat cultivation has been suffered from various problems, such as shortage of irrigation water low yields, traditional methods of farming, increases in input prices, shortage of good quality key inputs, and low usage of modern technology [4].

Pakistan ranks $36^{\text {th }}$ biggest country in the world regarding the geographical area and 6th in terms of population with an estimated population of 207.77 million todays [5]. The food and fiber for this huge population are being grown in Pakistan. Sindh is a major food producing province of Pakistan with major share in agricultural production. In Sindh, district Ghotki has very fertile land, and main crops it produces are cotton, wheat, sugarcane and rice which are irrigated through Ghotki feeder of Guddu barrage irrigation system. The population of Ghotki district, presently comprising five talukas Ghotki, Mirpur Mathelo, Daharki, Ubauro, Khan Garh and population is 10,37000 . The district is divided into three clear physical parts i, desert area ii, cultivable area and iii, flooded area (Katcha). The district Ghotki is spread over an area of 6,365 sq.km or 636472 hectares, in which desert constitutes 10117 hectares of land.

Accurate assessment of water demand for agriculture sustainability is an important issue in a globally changing climate and environment, where water is becoming a scarce but essential resource. Water is most important limiting natural resource nowadays, and in Pakistan, more than $70 \%$ of water is being utilized for irrigation. Shortage of surface and underground water, as well as the untimely availability of irrigation water, adversely affects the sowing, growth, and yield of crops. Hence, timely estimation of area under cultivation of different crops will be helpful in the estimation of total water needed for growing crops in the country. Thus, management of irrigation water based on timely information about available water resources and the total water demand is highly efficient.

The traditional approach of crop estimation in Pakistan involves complete enumeration of agricultural lands for estimating crop acreages and sample surveys based on crop cutting experiments for estimating crop yield. The crop production estimates are obtained by taking a yield of crop acreage and the corresponding area under cultivation. The yield surveys are fairly extensive with plot yield data collected under a complex sampling design that is based on a stratified multistage random sampling design. In each district, tehsils from the strata, the Deh in a block forms the primary sampling unit, the fields under the crop from second stage unit and at the third stage of sampling a plot of specified dimensions within a field is selected at each stage of sampling. Though based on strong physiological and physical concepts, these surveys are poor predictors when spatial variability in soils, stresses or management practices are present.

Remote sensing has emerged as one of the cost-effective and time-saving technology in many fields of Science. It has been matured and become operational for natural resources survey, monitoring, and management [6]. Especially in the field of agriculture; it is being implemented to identify the location-specific features for further interventions. Identification of different crop coverage is a very important technique, which provides vital information regarding the type and extent of crop cultivated in a particular area. This information has immense potential in the planning for further cultivation activities and optimal land use planning [7]. Remote sensing satellite data can also be used for improving the crop yield estimation through crop cutting experiments and also for developing models for crop yield using historical data, meteorological data along with the remotely sensed satellite data.

The Government of Pakistan is in the process of promoting and diversifying its application and capacity for an effective mechanism to make certain crop monitoring and forecasting system. Pakistan's Ministry of National Food Security and Research effort to raise the mobility. Human resource development and service structure of Crop Reporting Service (CRS) in the country. The ministry further 
preferred to invest in cross-cutting technology which includes GIS and Remote Sensing (RS) for collecting spatial data on crops sector for timely interventions. A satellite-based crops statistics of major crops which include wheat, rice, cotton, sugarcane, maize and potato since 2005 [8,9]. Pakistan Space and Upper Atmosphere Research Commission (SUPARCO), the space agency of Pakistan started developing crop area estimation procedure and crop yield models, based on the application of satellite remote sensing, GIS technology. Agronomy, agro-metrology, statistics and other allied disciplines.

To evaluate the reliability and precision of the remote sensing tools and the usefulness of Landsat 8 satellite data for mapping of cropped areas and predicting wheat and other major Rabi crops yield potential for district Ghotki, the present research study was performed. Based on the area under crops and crop water requirements, the irrigation water requirement of Ghotki district for Rabi season was also determined.

\section{Materials and Methods}

Study area

The research study was performed in district Ghotki in Sindh province of Pakistan. The district is located in northern part of the Sindh. District Ghotki is a gateway to upper Sindh bordering with Punjab province. It is situated between latitude $27^{\circ} 19^{\prime} 45.68^{\prime \prime} \mathrm{N}$, and $28^{\circ} 23^{\prime} 59.49^{\prime \prime} \mathrm{N}$ and longitude $69^{\circ} 09^{\prime} 51.01^{\prime \prime} \mathrm{E}$ and $70^{\circ} 11^{\prime} 52.66^{\prime \prime E}$, and on an average elevation of 71 meters above mean sea level. The river Indus flows along the western boundary of the district and its direction of flow from North to South. District Ghotki is bounded by the district Rahimyar Khan (Punjab) in the northeast, Kashmore/ Kandhkot in the west and north-west, Sukkur in the south and southwest and India (Rajasthan) in the east (Figure 1). The district Ghotki is divided administratively into 5 talukas viz. Ghotki, Mirpur Mathelo, Daharki, Ubauro and Khan Garh. The district has 40 Union Councils and 248 Dehs (Table 1). The river floodplain is called Katcha, bounded by safety bunds and riverine forests abound in the area. The total area of the district under forest and Katcha is 402,578 acres, which is about $25.88 \%$ of total area. The topography of Ghotki district is divided into three clear physical parts: i. Desert area; ii. Cultivable area and iii. Flood plains (Katcha). The district Ghotki is spread over an area of 6,365 km2 or 636472 hectares, in which desert constitutes nearly half of the land. The desert area, which consists of windblown sand dunes known as Achhro Thar (White Desert), starts from Sanghar district to Choolistan (Punjab) along with Indian border state of Rajasthan. It goes along with a southern belt of the district. The cultivable area is located between desert and flood areas at the center of the district. It is a fertile area of Sindh which is irrigated through Ghotki Feeder of Guddu barrage irrigation system. The important crops grown in the district are rice, maize, wheat, cotton, sugarcane and different varieties of pulses. The soils of Ghotki are also divided into three border categories; i. Loamy and some sandy stratified soils of young flood plains, ii. Loamy and clayey soils of older river plains, iii. Rolling to hilly sandy soils of Aeolian deserts.

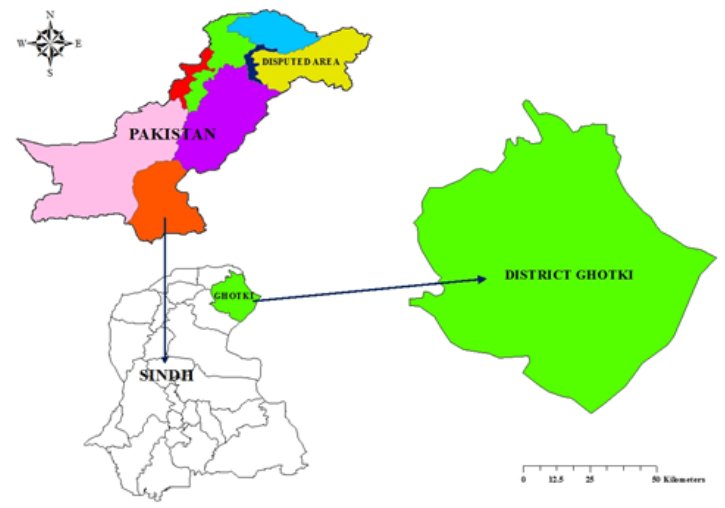

Figure 1: Location map of district Ghotki.

\begin{tabular}{|c|c|c|c|c|}
\hline S.No & Taluka & $\begin{array}{c}\text { Total } \\
\text { no: of } \\
\text { UCS }\end{array}$ & Deh & Name \\
of UCS & 73 \\
\hline 1 & Ghotki & 14 & $\begin{array}{c}\text { Ghotki I, II, III, Qadirpur, } \\
\text { Berreri, Bagho Daho, Umar } \\
\text { Daho,Adil Pur, Ali Bagh, } \\
\text { Bandh, Ruk, Hussain Beli }\end{array}$ & \\
\hline 3 & $\begin{array}{c}\text { Mirpur } \\
\text { Mathelo }\end{array}$ & 8 & $\begin{array}{c}\text { Mirpur, Dhangro, Jarwar, } \\
\text { Yaro Lund, Wahi Ghoto, } \\
\text { Sono Pitafi, }\end{array}$ & 54 \\
\hline 4 & Daharki & 6 & $\begin{array}{c}\text { Daharki, Raharki, Dad } \\
\text { Laghari, Keenjhar, Berruta, } \\
\text { Sain Dino Malik }\end{array}$ & 47 \\
\hline 5 & $\begin{array}{c}\text { Khan } \\
\text { Garh }\end{array}$ & 4 & $\begin{array}{c}\text { Ubaro, Kamo Shaheed, } \\
\text { Khambara, Wasti Jeewan } \\
\text { Shah, Ranwati, Jungle Malik, } \\
\text { Langho, Chandia }\end{array}$ & 64 \\
\hline \multicolumn{2}{|c|}{ Total } & 40 & $\begin{array}{c}\text { Khanpur, Bhetoor, Lohi, } \\
\text { Mithri }\end{array}$ & 37 \\
\hline
\end{tabular}

Table 1: Administrative units of district Ghotki. 


\section{Population}

The population of the district is about 1,646,318 [10]. with a geographical area of about 6383 sq.km. About $24.5 \%$ of the population lives in urban areas while $75.5 \%$ of the population lives in rural areas. As per census 2017, the district Ghotki has a population density of 271 persons per square $\mathrm{km}$. The Ghotki taluka covers an area of 763sq.km (12\%) with population 505,998, Mirpur Mathelo covers an area of 593 sq.km (10\%) with population 327,944, Daharki covers 2088 sq.km (34\%) with population 310, 079 while Ubauro covers 653 sq.km (11\%) with population of about 353,289, and Khan Garh covers an area 1986 sq.km (33\%) and population 149,008 . About $70 \%$ of the population is engaged in the agriculture sector.

\section{Climate and irrigation}

The district Ghotki is warm and gets a very little annual rainfall. January is the coldest month when the mean minimum temperature falls to $7^{\circ} \mathrm{C}$ while May and June are the hottest months with the mean maximum temperature of $45^{\circ} \mathrm{C}$. Precipitation is highly erratic with an annual average of about $130 \mathrm{~mm}$. The monsoon dominates from July to September every year. The climate of Ghotki is suitable for growing fruit and vegetable crops, like banana, dates, mangoes, lemon, carrot, reddish, cabbage, spinach, onion, green chilies, etc. Main crops grown in the district are sugarcane, wheat, and cotton.

\section{Irrigation}

The district Ghotki consists of the flat and fertile agricultural lands. The Ghotki Feeder originating from Guddu barrage passes through the entire district and irrigates almost all of the agriculture lands through a network of minors, distributaries, watercourses and field channels. While Rainee Canal irrigates northern and some desert areas of the district.

\section{Ground trothing survey}

The ground trothing survey was conducted during Rabi season during December and January 2016-17 using a Geographical map and Garmin GPS map 62s system device. A Proforma was developed for getting the primary data from the field survey. The Proforma contained information of longitude, latitude, the name of the union council, taluka name, crop name, bare land, orchard, settlement and water body about the sampled location. The ground trothing survey consisted type of crops for estimating crop acreage of major crops in district Ghotki. Yield survey was based on farmer's response which was conducted for predicting the current crop yield of wheat and other major crops in district Ghotki. For estimation of crop acreage, random sampling of crops, bare land, built in areas, orchards were performed. Nearly all union councils were visited, and required data was gathered. The spatial distribution of the field data sampling points is shown in Figure 2.

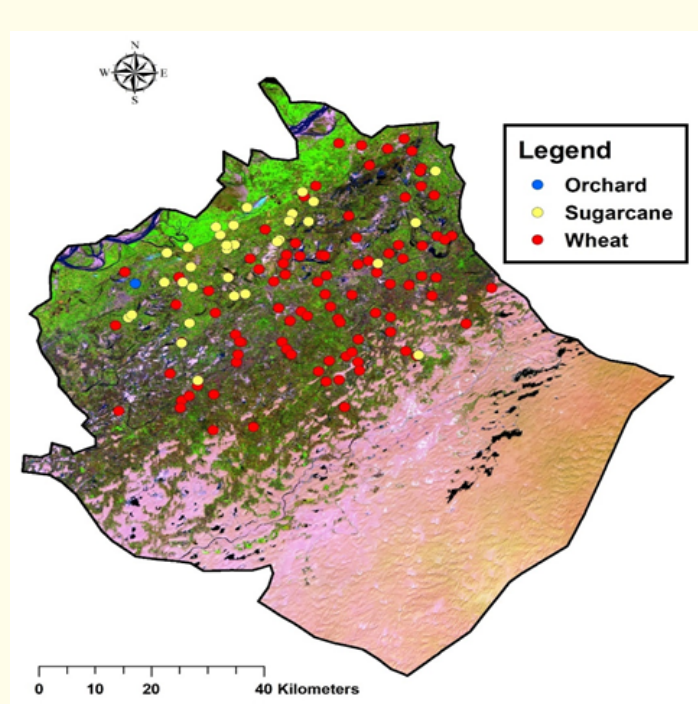

Figure 2: Spatial distributions of the field data sampling locations in district.

\section{Conventional cropped area estimation}

In many countries crop yield is estimated based on conventional techniques of data collection through field visits and reports. Such reports and data are subjective, costly, time-consuming and prone to large errors due to incomplete ground observation, leading to poor crop yield assessment and crop area estimation [11]. In most countries, the data about crop acreage becomes available too late for the appropriate actions to be taken to avert food shortage $[12,13]$.

In Sindh province, the area under crops is estimated through sample surveys by the statistical staff of the provincial Crop Reporting Services (CRS), Department of Agriculture. The subjective judgment of the agricultural extension staff for all the major crops in Sindh provides the preliminary estimates of production. Crop cutting surveys for wheat, cotton, and rice are conducted for the final estimates. The opinion survey and judgment of the provincial 
department conducted by statistical staff of agricultural extension are subjective to crop production estimates of the remaining crops. The sub-committee comprising of the representatives of the Provincial Department of Agriculture, Revenue, Irrigation, and Planning and Development check the final estimates. The preliminary estimates are approved by the secretary of the Ministry of Agriculture and finally approved by the Provincial Coordinating Committee on agricultural statistics, which are then made public.

\section{Historical data of cropped area and yield}

The historical data of crop yield was used to develop a regression model for prediction of crop yield. The record of 20 to 30 years of data with sufficient accuracy is required to estimate extreme values. The historical data of crop acreage, total production and crop yield of the major crops from Rabi season 2007-08 to 2016-17 was collected from the Crop Reporting Service (CRS), Department of Agriculture, Sindh and from Bureau of Statistics, Government of Pakistan. Data on irrigation water withdrawal for the district Rabi 2016-17 was also collected from CRS, Sindh.

\section{Satellite data}

The landsat

The Landsat satellite data is used for identification of crop types, and estimation of crop acreage in arid and semi-arid regions. In these areas crop diversity is less, dryland crop production is less, soils are warm and well-drained, and fields are sown entirely with one crop type [14]. The first Landsat satellite (named The Earth Resources Technology Satellite, ERTS-1) was launched in 1972 which opened an era of monitoring earth's terrestrial surface by space-borne remotely sensed imagery. The Landsat program has continuously collected spectral information from earth's surface. The first three satellites were similar, and their payloads consisted of two optical instruments, a multispectral sensor (Multi Spectral Scanner or MSS) and a series of video cameras (Return Beam Vidicons or RBVs) having the spatial resolution of $68 \mathrm{~m}$ by $83 \mathrm{~m}$ with four bands whereas Landsat 3 had an extra thermal band. The next two satellites (Landsat 4 and 5) were equipped with two multispectral sensors, i.e., a Multi Spectral Scanner (MSS) and a Thematic Mapper (TM). The last generation of Landsat satellites started with failure, for Landsat 6 was lost just after its launch in October 1993. Landsat 7 was launched in 1999 which is equipped with a multispectral sensor known as the Enhanced Thematic Mapper Plus or ETM+. Its spatial resolution was $30 \mathrm{~m}$ and ETM+ also con- tains a $15 \mathrm{~m}$ panchromatic band. NASA successfully launched the Landsat 8 on February 11, 2013, and operation was transferred to the USGS. Landsat 8 data collected from April 11, 2013, with an Operational Land Imager (OLI) and Thermal Infrared Sensors (TIRS) are available to download free.

Acquisition of satellite imagery

Landsat 8 satellite images of the study area Worldwide Reference System (WRS-2) path 151, row 41, processing level IT) for Rabi season 2016-17 were acquired and analyzed in this study. These images were carefully selected to avoid cloud cover and haze over the study area to evade problems with calibration of the imagery. The Landsat 8 satellite scans the entire earth in every 16 days within an 8-day offset from Landsat 7. Data collected by the OLI and TIRS sensors onboard, the images are available to download free from Global Visualization Viewer (GloVis), Earth Explorer, or via the Landsat look viewer within 24 hours of the reception. Two images (start and end of Rabi season) were utilized for the present study from GloVis for Rabi 2016-17 Table 2.

\begin{tabular}{|l|c|c|c|c|}
\hline S.No & Landsat Scene ID & $\begin{array}{c}\text { Path/ } \\
\text { Row }\end{array}$ & $\begin{array}{c}\text { Day of } \\
\text { Year } \\
\text { (DOY) }\end{array}$ & $\begin{array}{c}\text { Image } \\
\text { Acquisition } \\
\text { Date }\end{array}$ \\
\hline 1 & LC81510412016353 & $151 / 41$ & 353 & Dec \\
\hline 2 & LGN02 & & & 18, \\
& LC81510412017083 & $151 / 41$ & 83 & 24, \\
\hline
\end{tabular}

Table 2: Landsat 8 images used for the study.

\section{Satellite images processing with ArcGIS 10.3}

Extraction of area of interest (AOI)

The area of interest, district Ghotki was extracted from entire scenes of Landsat 8 obtained from GloVis for the Rabi season 201617 (Table 2) by running "Extract by Mask" tool using ArcGIS 10.3. The "Extract by Mask" algorithm is a spatial analyst tool used in ArcGIS to extract a raster by a polygon feature or another input raster. For extraction of AOI, shapefile of district Ghotki was used as a mask. 


\section{Classification of satellite imagery}

The task of extracting information from raster image is known as image classification. Thematic maps can be created from the resulting raster after image classification. Basically, the images are classified by supervised classification and unsupervised classification. In supervised classification, classification of an image can be done by spectral signatures obtained from training samples. The unclassified satellite imagery of AOI was processed in ArcGIS 10.3 software using supervised classification. For this data was trained for different classes, viz. wheat, sugarcane, water, cities/barren land, etc. by integrating geo referenced field data. Thus, signature files were created for land cover in district Ghotki. The area under each class was determined by converting raster data into vector data.

\section{Normalized Difference Vegetation Index (NDVI)}

Normalized Difference Vegetation Index (NDVI) was computed for each satellite image using red (B4) and near-infrared bands (B5) of Landsat 8 image of AOI. It was computed using map algebra tool through the following relation:

NDVI $=(\rho$ nir $-\rho r e d) /(\rho$ nir $+\rho r e d)$

Where

pnir $=$ Near Infrared band

pred $=$ Red band

NDVI value usually varies from -1 to +1 where the values near to zero suggest no green leaves. The values in the direction of +1 (0.8-0.9) suggest the maximum possible density of the lush green vegetation.

Normalized Difference Vegetation Index (NDVI) of different years for Ghotki obtained from the GLAM (Global Agriculture monitoring) Pakistan (Figure 3). GLAM is a MODIS based web portal which is designed and operated by University of Maryland (America). The GLAM shows vegetation conditioning and analysis of various spatial and temporal scales. NDVI of the district Ghotki for Rabi from 2007-08 to 2016-17 was obtained from the GLAM.

Data and statistical wheat yield models

Normalized Difference Vegetation Index of Ghotki district was associated with a historical yield of wheat to develop an NDVI based statistical yield model for the wheat crop. The historical data of wheat yield (tons/ha) of ten years 2006-07 to 2016-17 was collected from CRS for district Ghotki. The yield data were plotted against respective peak NDVI (March) each year and by adding a linear regression trendlines. NDVI based statistical regression yield model of the wheat crop was developed.

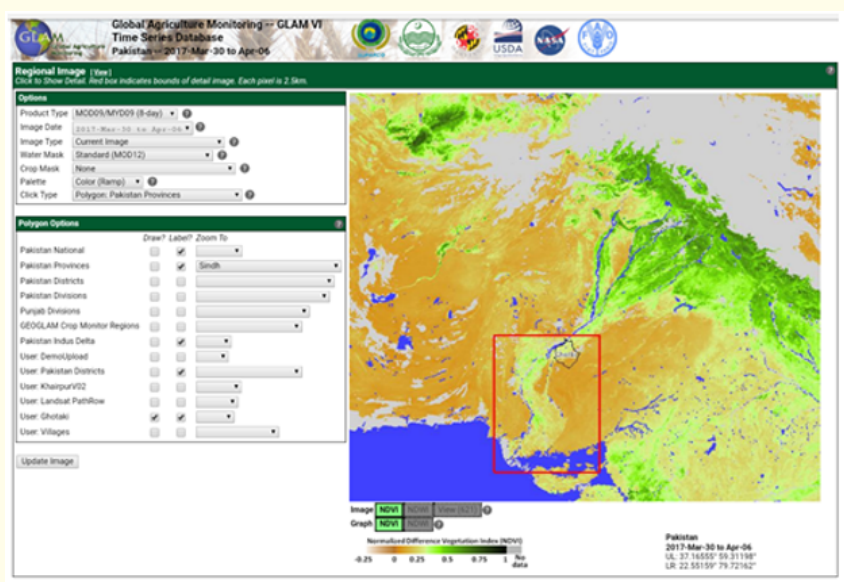

Figure 3: Global Agriculture Monitoring (GLAM) web portal.

\section{Crop water requirements}

The irrigation water requirement for wheat crop as well as for entire Rabi season of Ghotki was calculated by multiplying the area under each crop with its water requirements. The sum of crop water requirement of all crops grown in district led to an estimation of overall irrigation water requirements of district Ghotki during Rabi season 2016-17. The predicted crop water requirement was then compared to the reported data by Crop Reporting Service (CRS), Sindh.

\section{Temporal variation in vegetation}

Temporal variation in the vegetation of district Ghotki was quantified by comparing near-infrared band (band 5) of two images acquired at different dates during Rabi season. A change detection algorithm embodied in ArcMap images analysis window was run which computed the discrepancy among two raster or image service layers, the resulting raster image depicted increase, decrease or no change in the vegetation of the district Ghotki.

\section{Results and Discussions}

In district Ghotki, the sowing of crops in Rabi season starts every year from October and harvesting is initiated at the end of 
GIS Based Approach Estimation of Area under Wheat and Other Major Rabi Crops in District Ghotki and Corresponding Irrigation Water Requirement

March. Wheat, sugarcane, and various vegetables are the main Rabi crops of the district. In this chapter, the results of the research work based on historical record, field survey and Landsat 8 data which are described and discussed.

Historical crop data

\section{Wheat crop}

The Crop Reporting Services (CRS) Sindh reported about the area under wheat crop, production, and yield given in (Table 3). As per that data, for the period 2007-08 to 2015-16, the maximum area under wheat crop (102554 ha) was during 2015-16 in Ghotki district. However, the maximum wheat production (409902 tons) was obtained during 2010-11. Also, the wheat yield 4.082 tons/ ha was also higher during the same year. The area under wheat crop was smaller (90130 ha) during the year 2007-08. The timely availability of canal water and climatic factors might be the main reasons for variation in cultivated area, crop yield and total production.

\begin{tabular}{|l|c|c|c|}
\hline \multirow{2}{*}{ Year } & \multicolumn{3}{|c|}{ Wheat } \\
\cline { 2 - 4 } & Area (ha) & $\begin{array}{c}\text { Production } \\
\text { (tons) }\end{array}$ & Yield (Tons/ha) \\
\hline $2007 / 08$ & 90130 & 329626 & 3.657 \\
\hline $2008 / 09$ & 97480 & 363251 & 3.726 \\
\hline $2009 / 10$ & 103724 & 364386 & 3.513 \\
\hline $2010 / 11$ & 100415 & 409902 & 4.082 \\
\hline $2011 / 12$ & 100265 & 403361 & 4.022 \\
\hline $2012 / 13$ & 100232 & 359010 & 3.581 \\
\hline $2013 / 14$ & 101485 & 390906 & 3.851 \\
\hline $2014 / 15$ & 100885 & 338523 & 3.355 \\
\hline $2015 / 16$ & 102554 & 384658 & 3.750 \\
\hline
\end{tabular}

Table 3: Historical data of wheat cropped area, production and yield of district Ghotki 2007-08 to 2015-16.

Source: CRS Hyderabad, Sindh.

A good relationship between the wheat cropped area and the crop production was obtained with a coefficient of determination of $\mathrm{R}^{2}=0.852$ as shown in (Figure 4). The graph shows that the wheat grain production in the district linearly increased with increase in cropped area with a statistical regression relationship given below:

Wheat production (tons) $=5.494 \times$ cropped area (ha) -165607

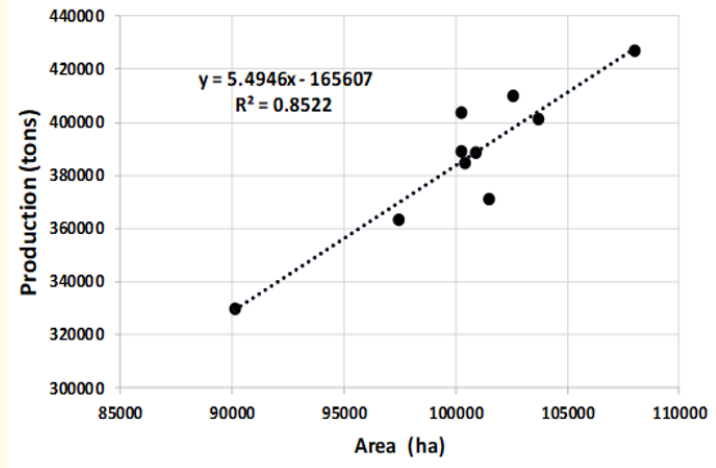

Figure 4: Relationship between wheat cropped area and total wheat production in district Ghotki.

\section{Sugarcane crop}

The area under sugarcane crop, production, and yield in district Ghotki recorded by the CRS, is presented in (Table 4). The data in the table shows that sugarcane crop was cultivated on an area of about 50236 ha during 2015-16 in Ghotki district which is the maximum area from 2007-08 to 2015-16. The data shows that area under sugarcane increase linearly with time might be due to the increasing number of sugar mills in the district. Also, the cane production of 2929661 tons was the maximum during the same year. While the crop yield of 64.248 tons/ha was recorded highest during the year 2007-08. The area under crop and production of sugarcane was lowest during the year 2010-11. It might be due to flooding of sugarcane fields which are concentrated in katcha area of the district during flood 2010.

\begin{tabular}{|l|c|c|c|}
\hline \multirow{2}{*}{ Year } & \multicolumn{3}{|c|}{ Sugarcane } \\
\cline { 2 - 4 } & Area (ha) & $\begin{array}{c}\text { Production } \\
\text { (tons) }\end{array}$ & Yield (Tons/ha) \\
\hline $2007 / 08$ & 8380 & 538403 & 64.248 \\
\hline $2008 / 09$ & 5893 & 298816 & 50.706 \\
\hline $2009 / 10$ & 4762 & 300303 & 63.062 \\
\hline $2010 / 11$ & 2452 & 148328 & 60.492 \\
\hline $2011 / 12$ & 6511 & 408669 & 62.765 \\
\hline $2012 / 13$ & 5296 & 303617 & 57.329 \\
\hline $2013 / 14$ & 25060 & 1510989 & 60.294 \\
\hline $2014 / 15$ & 37046 & 1977358 & 53.375 \\
\hline $2015 / 16$ & 50236 & 2929661 & 58.3179 \\
\hline
\end{tabular}

Table 4: Historical data of sugarcane cropped area, production and yield of district Ghotki from 2007-08 to 2015-16.

Source: CRS Hyderabad, Sindh. 
A strong linear relationship, with a coefficient of determination of $\mathrm{R}^{2}=0.995$ was observed between the sugarcane cultivated area and the total cane production in the district Ghotki as shown in (Figure 5) The graph shows that the sugarcane production in the district linearly increased with increase in cropped area with a statistical regression relationship given below:

Sugarcane production (tons) $=56.69 \times$ cropped area (ha) $+17782$ (3)

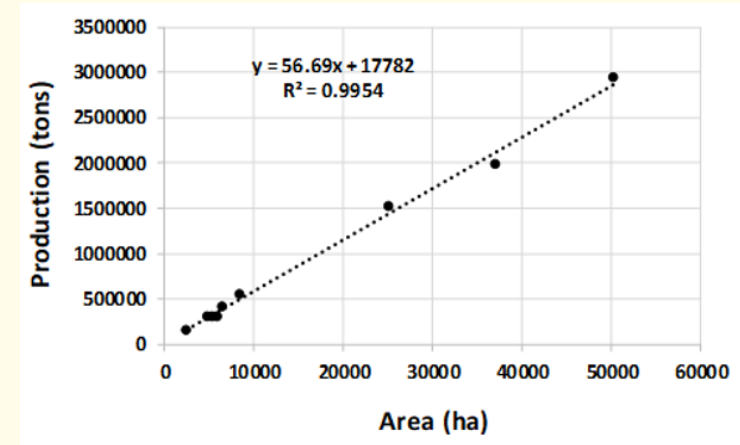

Figure 5: Relationship between sugarcane cropped area and total sugarcane production in district Ghotki.

Crop area and yield estimation based on satellite data

Classification of Satellite Imagery Acquired on December 18, 2016.

The unclassified satellite imagery of Area of Interest (AOI), i.e. district Ghotki, in Pseudo Natural Color captured by Landsat 8 on December 18, 2016, is shown in (Figure 6). The imagery of district in the figure shows that Rabi crop was still not sown over the entire agricultural lands.

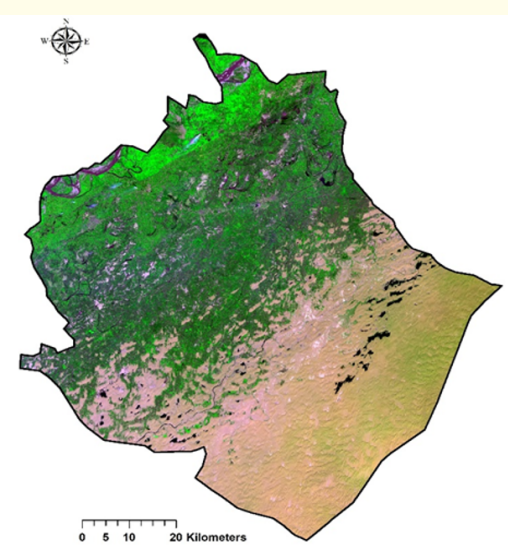

\begin{tabular}{|l|c|c|c|}
\hline S.No & Land Utilization & $\begin{array}{c}\text { Area } \\
\text { (ha) }\end{array}$ & $\begin{array}{c}\text { Percentage of Total } \\
\text { Geographical Area }\end{array}$ \\
\hline 1 & Wheat & 104703 & 16.45 \\
\hline 2 & Sugarcane & 48424 & 7.61 \\
\hline 3 & Other Crops & 65187 & 10.24 \\
\hline 4 & Waterbody & 41029 & 6.45 \\
\hline 5 & $\begin{array}{c}\text { Towns, Villages, Barren } \\
\text { Land, Roads, etc. }\end{array}$ & 377129 & 59.25 \\
\hline \multicolumn{2}{|c|}{ Total } & 636472 & 100 \\
\hline
\end{tabular}

Table 5: Land utilization of district Ghotki on December 18, 2016.

Figure 7 shows the classified image December 18, 2016, of Ghotki which is classified with supervised classification using maximum likelihood classification algorithm whereas (Table 5) shows the resulting estimation of area under major crops, water body, bare land/ towns/villages in the district. As in image the total wheat area is about 104703 ha or $16.45 \%$ of the total geographical area. It is clear in classified imagery that wheat crop was the major crop in the district during Rabi season 2016-17. While the area under sugarcane covered about 48424 ha which is about $7.61 \%$ of the total geographical area while other crops were cultivated on about 65187 ha which covered $10.24 \%$ total geographical area. Water covered an area of about 41029 ha which is $6.45 \%$ of the total geographical area. The area under towns/villages roads etc. is 377129 ha which is $59.25 \%$ of the total geographical area of the Ghotki.

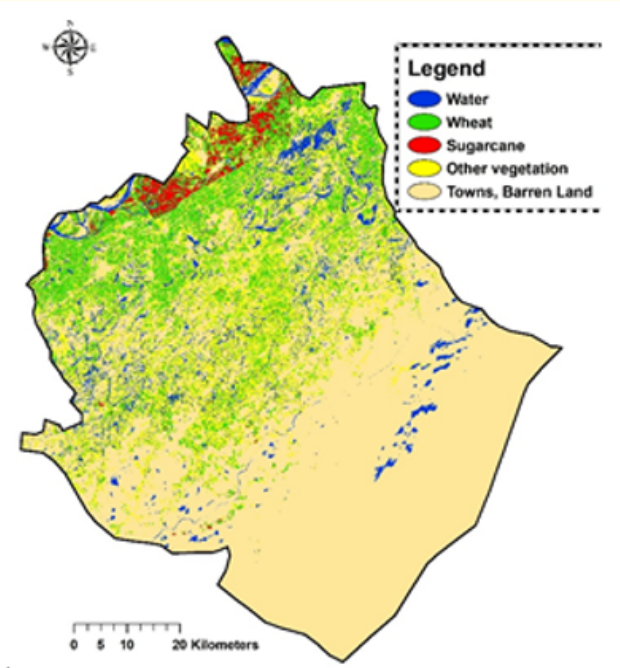

Figure 7: Classified satellite image (Dec. 18, 2016) of district Ghotki.

Figure 6: Unclassified satellite image (Dec. 18, 2016) of the district Ghotki. 
Classification of satellite imagery acquired on March 24, 2017

The unclassified imagery of Ghotki district in Pseudo Natural Color obtained on March 24, 2017, by Landsat 8 satellite is shown in (Figure 8). The imagery in the figure shows that almost all the agricultural lands are covered with different Rabi crops.

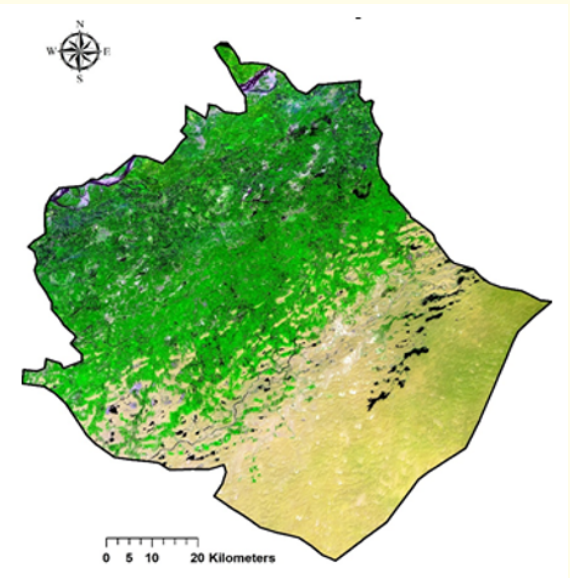

Figure 8: Unclassified satellite image (Mar. 24, 2017) of the district Ghotki.

Figure 9 shows the classified image of Ghotki captured on March 24, 2017, whereas (Table 6) shows the resulting estimation of the area of major crops, water body, and bare land/towns/villages in district Ghotki. The total wheat area is estimated from the image as 123427 ha which is $19.39 \%$ total geographical area of the district. While Sugarcane covered total an area of about 49116 ha which is about $7.72 \%$ of the total geographical area and other total crops area is 67299 ha which covered $10.57 \%$ of the total geographical area. Water covered 41452 ha which is $6.51 \%$ total geographical area. The area under towns/villages roads etc.is 355178 ha which covers $55.80 \%$ of the total geographical area of district Ghotki.

\begin{tabular}{|c|c|c|c|}
\hline S. No & Land Utilization & $\begin{array}{c}\text { Area } \\
\text { (ha) }\end{array}$ & $\begin{array}{c}\text { Percentage of Total } \\
\text { Geographical Area }\end{array}$ \\
\hline 1 & Wheat & 123427 & 19.39 \\
\hline 2 & Sugarcane & 49116 & 7.72 \\
\hline 3 & Other Crops & 67299 & 10.57 \\
\hline 4 & Waterbody & 41452 & 6.51 \\
\hline 5 & $\begin{array}{c}\text { Towns, Villages, Bar- } \\
\text { ren Land, Roads, etc. }\end{array}$ & 355178 & 55.80 \\
\hline \multicolumn{2}{|c|}{ Total } & 636472 & 100 \\
\hline
\end{tabular}

Table 6: Land utilization of district Ghotki on March 24, 2017.

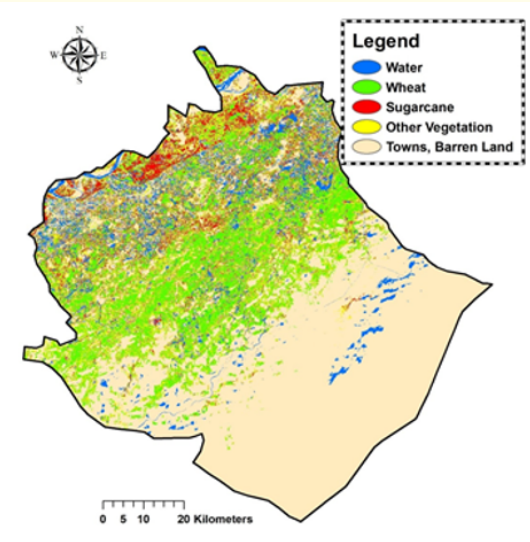

Figure 9: Classified satellite image (Mar.24,2017) of district Ghotki.

Vegetation mask

Vegetation mask of the area of study is presented in (Figure 10) which shows vegetation of district in December 2016 and March 2017. It is clear in the image the area under different crops and orchards. The green color in imagery shows the area under flora and white color shows uncultivated land/barren land, city, roads, ponds, canals, etc.

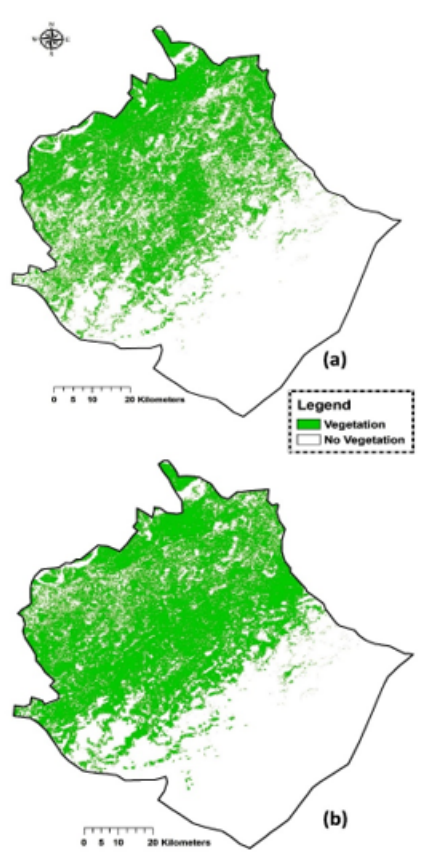

Figure 10: Vegetation mask of district Ghotki during Rabi 2016-17 (a) Dec. 18, 2016, and (b) Mar. 24, 2017. 
The Landsat image of December 18, 2016, indicated that the total estimated area of vegetation was about 218314 ha which is $34.30 \%$ of the total geographical area while no vegetation was 418158 ha which $65.69 \%$ of the total geographical area. The image of March 24, 2017 indicate that the area estimated under vegetation was about 239842 ha which is $37.68 \%$ of the total geographical area and 396630 ha is the area under no vegetation which is $62.31 \%$ of the total geographical area of district Ghotki.

\section{NDVI of district Ghotki}

Normalized Difference Vegetation Index (NDVI) of the district Ghotki was calculated for both images are shown in (Figure 11). The peak NDVI for the images captured on December 18, 2016, and March 24, 2017, were 0.42 and 0.47 respectively. It confirms that NDVI of an area increases with the age/height of the crop. The NDVI reaches at its peak when the crop reaches at its maturity.
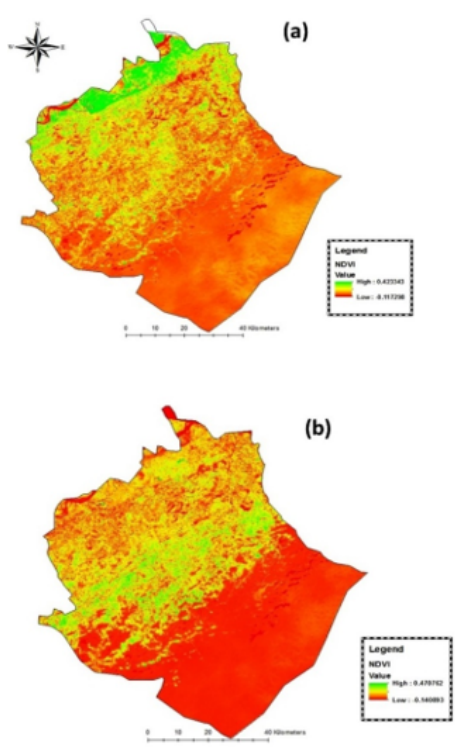

Figure 11: NDVI for Rabi 2016-17 for district Ghotki

(a) December 18, 2016, and (b) March 24, 2017.

\section{Relationship between wheat Yield and NDVI}

The NDVI (based on MODIS satellite data) of district Ghotki, obtained from GLAM using "Pakistan Crop Mask," from the year 200708 to 2016-17 is plotted against yield of wheat crop of respective years as shown in (Figure 12).

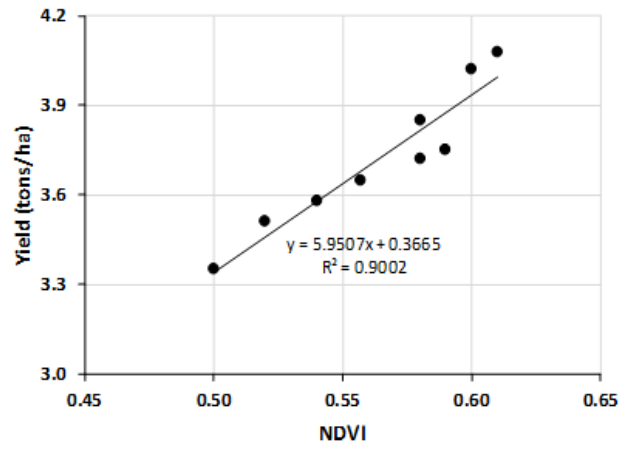

Figure 12: Relationship between NDVI and the wheat Yield.

A strong linear relationship between NDVI and wheat Yield of district Ghotki was observed with a coefficient of determination of $\mathrm{R}^{2}=0.90$. Thus, a statistical regression Yield model was developed, which is presented in the equation 4 .

Wheat Yield (tons/ha) $=5.95 \times \mathrm{NDVI}+0.3665(4)$

Temporal variation in vegetation

The temporal variation in the vegetation of Ghotki from December 18, 2016, to March 24, 2017, is shown in (Figure 13). The increase in the vegetation is displayed by green color, whereas white color shows no change in the vegetation of Ghotki district. The area with red color represents a decrease in the vegetation. It depicts that vegetation increased on the area of about 21529 ha (3.38\%) of the district.

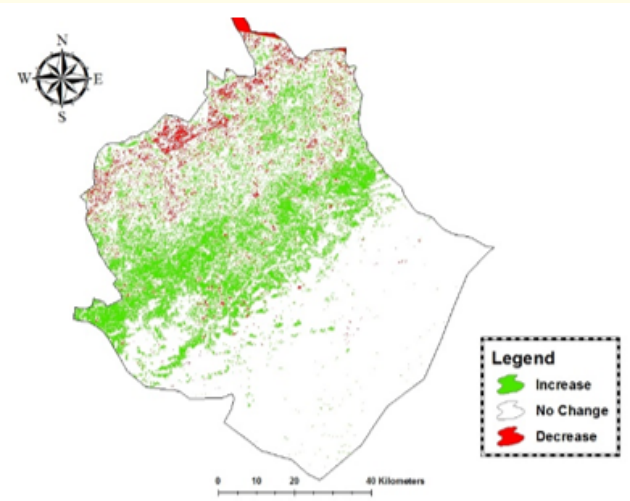

Figure 13: Temporal variation in vegetation of Ghotki from December 18, 2016, to March 24, 2017. 


\section{Irrigation water requirement}

The total crop water requirement of Ghotki district for Rabi season 2016-17 is estimated from the cropped area and the corresponding crop water requirement given in (Table 7). The water requirements of mentioned crops for Rabi season were taken from [15]. Water requirement for sugarcane is $1.8 \mathrm{~m}$ (for the whole season), which is divided as $1.2 \mathrm{~m}$ in Kharif and $0.6 \mathrm{~m}$ in Rabi period.
As per satellite-based estimated cropped area and crop water requirement given by [16], the total irrigation water required for the Rabi season 2016-17 was for Ghotki district was estimated as 0.962 million acre-feet (MAF). The irrigation water delivered by the SIDA/PID to the district for the Rabi season was $0.72 \mathrm{MAF}$ at the field level. Thus, a shortfall of 0.242 MAF (about 25.1\%) might have been supplemented from other sources of water, i.e., groundwater, rainfall, etc.

\begin{tabular}{|c|c|c|c|c|c|c|}
\hline Crop & $\begin{array}{l}\text { Area } \\
\text { (Ha) }\end{array}$ & Area $\left(m^{2}\right)$ & $\begin{array}{l}\text { CWR For } \\
\text { Rabi (m) }\end{array}$ & $\begin{array}{c}\text { Total Water } \\
\left(\mathrm{m}^{3}\right)\end{array}$ & Total (MAF) & $\begin{array}{c}\text { SIDA Delivered } \\
\text { (MAF) }\end{array}$ \\
\hline Wheat & 123427 & 1234273699 & 0.45 & 555423164 & \multirow{4}{*}{0.962} & \multirow{4}{*}{0.72} \\
\hline Sugar cane & 49116 & 491163507 & 0.6 & 294698104 & & \\
\hline Other crops & 67299 & 672993803 & 0.50 & 336496901 & & \\
\hline \multicolumn{4}{|c|}{ Total $\left(\mathrm{m}^{3}\right)$} & 1186618169 & & \\
\hline
\end{tabular}

Table 7: Calculation of irrigation water required for different crops based on crop acreage estimated from classified satellite imagery.

Accurate estimation of water requirement for growing various crops in different seasons plays a vital role planning and management of water resources. It is reported that about $40 \%$ of agricultural outputs and $60 \%$ of grain production globally is obtained from irrigated areas which together contribute $20 \%$ of the total arable land [17].

Traditionally crop area estimations in Pakistan contain a complete enumeration of agricultural lands and sample surveys based on crop cutting experiments for estimating crop yield. With the use of satellite technology in agriculture, crop area estimates worldwide are carried out using remote sensing. The present study on area estimation is based on the use of remote sensing technology. The conclusion of the study is given below:

\section{Conclusion}

Based on ground trothing data, historical data reported by CRS, Sindh, and the Landsat 8 satellite data and their analysis the following conclusions are drawn:

- $\quad$ Based on satellite data, wheat was estimated as a major Rabi crop of Ghotki during 2016-17, which was cultivated on the land of about 123427 ha, occupying about 19.39\% of the total geographical area of the district or about 51.46 percent of the total irrigated area of the district.
- $\quad$ Sugarcane was second major Rabi crop, which was grown over an area of about 49116 ha in 2016-17, occupied about $7.72 \%$ of the total geographical area of the district or about 20.47 percent of the total irrigated area of the district.

- $\quad$ A good relation between cultivated area and the total production of the wheat and sugarcane with $\mathrm{R}^{2}=0.85$ and $\mathrm{R}^{2}=0.97$ respectively was observed.

- A good linear and positive relationship between the wheat crop yield and the NDVI with a coefficient of determination of $\mathrm{R}^{2}=0.90$ was noted. Thus, wheat crop yield in the district can be estimated using NDVI based regression model developed in the present study.

- The total irrigation water requirement for the district during Rabi season 2016-17 was 0.962 MAF while the irrigation water distributed by the SIDA/PID to the Ghotki for the Rabi period was $0.72 \mathrm{MAF}$ at the field.

Thus, a shortfall of 0.242 MAF (about 25.1\%) might have been supplemented from other sources of water, i.e., groundwater, ponds, lakes, and rainfall, etc.

\section{Recommendations}

A research study has been conducted in one district for a one agricultural season. 
- $\quad$ Cropped area estimation with high-resolution imagery should be carried out for better accuracy.

- $\quad$ More studies in other districts, considering major and minor crops and cultivation seasons, should be carried out.

- $\quad$ Remote sensing and GIS tools should be applied in other districts of Sindh for timely, accurate and reliable cropped area estimation and yield forecast of agricultural products as well as irrigation water requirements.

\section{Acknowledgment}

All priases and thanks to the Almighty Allah who gave me strength to complete successfully this work.

I would like to express my sincere thanks to Prof. Dr. Altaf Ali Siyal, US-Pakistan Centre for Advanced Studies in Water, Mehran University of Engineering and Technology Jamshoro for giving me an opportunity to work under his guidance and providing me essential resources to complete my research work. I am grateful to all faculty members of IWREM (Institute of Water Resources Engineering and Management) for their teaching and cooperation during my entire course of study.

My gratitude goes to my younger brother Syed Taswar Ali Shah and friend Sarkar Maqsood Ali Lashari who gave me tremendous support and assistance for the collection of the data during research work and prayer help in finishing of my work.

Finally, I would like to enhanced my expressions and thanks to my parents and family members especially to my mother who stood by me during some harsh moments of my life and support me during my research work.

\section{Bibliography}

1. Ahmad MD., et al. "Water savings technologies and water savings: Myths and realities revealed in Pakistan's rice-wheat systems". Research report (2007): 108. International Water Management Institute (IWMI), Colombo, Sri Lanka (2007).

2. Bussay A and Akhtar IH. "Crop Yield/Production forecasting and estimation technology for Kharif crops (cotton, rice and sugarcane)". Pakistan Space and Upper Atmosphere Research Commission, Islamabad, Pakistan 62 (2009): 25.

3. Falak Sher and Eatzaz Ahmad. "Forecasting wheat production in Pakistan". The Lahore Journal of Economics 13 (2008): 5785.
4. GOP. "Pakistan Economic Survey". Government of Pakistan (2008-09). Ministry of Food, Agriculture and Live Stock, Federal Beauru of Statistics Islamabad (2009).

5. Haig LA Sawasawa. "Crop yield estimation: Integrating RS, GIS and management factors, A case study of Birkoor and Kortigiri Mandals-Nizamabad district, India". (2003).

6. Joseph, G. "Fundamentals of remote sensing". University press, Hyderabad (2003).

7. Kahlown MA., et al. "Water quality issues and status in Pakistan. Proceedings of seminar on strategies to address the present and future water quality issues". Pakistan Council of Research in Water Resources Islamabad 123 (2003).

8. Kolm KE. "Evaluation of techniques for mapping land and crops irrigated by center pivots from Computer-Enhanced Landsat Imagery in part of The James River basin near Huron, South Dakota": U.S. Geological Survey Water Resources Investigations Report 85-4021; 24 (1985).

9. Ministry of Finance. "Economic Survey of Pakistan" (2014).

10. Mirbahar AA., et al. "Effect of water stress on yield and yield components of Wheat (Triticum Aestivum L. varieties". Pakistan Journal of Botany 41(3): (2009) 1303-1310.

11. Nuarsa IW., et al. "Spectral characterization of rice field using Multi-Temporal Landsat ETM+ data". International Journal of Remote Sensing and Earth Sciences 2 (2005) 65-7 (2005).

12. Omkar SN., et al. "Crop classification using Biologically-Inspired Techniques with high resolution satellite image". Journal of the Indian Society of Remote Sensing 36 (2009): 175-182.

13. Pakistan Bureau of Statistics Block wise provisional summary results of 6th Population and Housing Census-2017 (2017).

14. Rehman, O., et al. "RS-GIS based crop monitoring and forecasting System". National conference on sustainable agriculture in changing climate, Bara Gali, Pakistan (2011).

15. Reynolds, M., et al. "Estimation crop yields and production by integrating the FAO Crop Speci. C Water Balance model with real-time satellite data and ground-based ancillary data". International Journal of Remote Sensing 21 (2000): 3487-3508.

\section{Volume 3 Issue 12 December 2019 (C) All rights are reserved by Shoukat Ali Shah and Altaf Ali Siyal.}

